\title{
Should the State Control Tariffs?
}

\author{
Zaid $^{1}$, Farouk Aisha Dawaki², Sabit Kazeem Ololade ${ }^{3}$ \\ ${ }^{1}$ Universitas Muhammadiyah Yogyakarta, Indonesia \\ 2 Bage, Muhammad \& Partners Abuja, Nigeria \\ ${ }^{3}$ Magajin Gari and Co, Nigeria \\ ${ }^{1}$ Corresponding Author: zaidrusdianto@gmail.com \\ doi) http://dx.doi.org/10.18196/jgpp.811340 \\ Article Info
}

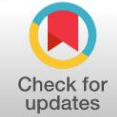

Article History;

Received:

2020-12-10

Revised:

2021-01-28

Accepted:

2021-02-10

\begin{abstract}
Tariffs or price control has been a controversial subject in recent years. The debate between legal experts and economists is still a hot topic in any discussion. Tariff control regulated in the work creation omnibus law seems to be a topic that must be discussed again regarding this regulation's urgency. Are specific prices so impressive that the government can intervene in regulating them? This article examines the urgency of rules regarding price controls to create a healthy competitive environment. After conducting a critical literature review, it was analyzed with critical analysis and looking at the objective of competition law was to maximize welfare by protecting competition. The results in this article indicated that the government could only intervene in regulating price-fixing only if companies' pricing could harm the country's economy and consumer welfare. The government, therefore, had an interest in regulating the price ceiling. Meanwhile, the price floor, which was believed to be pro-consumer and could promote consumer welfare had no interest and should not have been limited by the government.
\end{abstract}

Keyword: Price control; Price ceiling; Price floor.

\section{INTRODUCTION}

On October 5, 2020, the House of Representatives of the Republic of Indonesia (DPR RI) approved the Work Creation (Cipta Kerja) Omnibus Law Draft. The law, which was then officially passed on November 2, 2020, became Law of the Republic of Indonesia Number 11 of 2020 on Work Creation. The 1187-pages law regulating the Job Creation Law consists of 15 chapters and 186 articles. It started its controversy in the community before it was passed due to illegal flaws until the ratification. Besides, this law is also considered to be endangering the workers' welfare and society in general. Therefore, employment regulations have become a hot issue in this law, leading to rejection from various social elements.

However, speaking of welfare, regulations related to business competition that regulate price control should be a serious concern. In the applicable Work Creation Law, price control is regulated in Article 71, which regulates amendments to Law Number 36 of 1999 concerning Telecommunications wherein the amendment to Article 28 of the Telecommunications Law states that the Central Government can set a price ceiling and base price regarding public interests and fair business competition.

Previously, the state (through its ministry) also intervened in prices and tariffs in several service sectors, such as price control in the Regulation of the Minister of Transportation of the Republic of Indonesia Number PM 36 of 2016 on Basic Tariffs, Upper Limits, and Lower limits Tariffs for Intercity, Inter-Province, Economy Class Passenger Transportation on the Road by Public Bus Car. This regulation then became the spotlight and criticism of the Indonesian Competition Commission (KPPU), especially regarding the lower limit tariff's determination. In 
KPPU views, the lower limit tariff will impact inefficiency in the transportation service industry, which will result in high tariffs for consumers (Issetiabudi, 2017).

In 2019, the government issued two ministerial regulations regarding price control in the online ride-sharing and airfare sectors. In the online motorcycle taxi service sector, the Ministry of Transportation released Ministerial Decree Number KP 348 of 2019 on Guidelines for Calculating Service Cost for Using Motorcycles Used for Public Interests Conducted By An Applications. This regulation then becomes the attention of KPPU that the Ministry of Transportation should pay attention to the protection of the driver-partners, which is more important than controlling prices (lower limits) which tend not to pro-consumers (Maulandy, 2019).

In the airfare sector, the Minister of Transportation, through the Minister of Transportation Regulation Number 20 of 2019, which regulates the Procedure and Formulation for the Calculation of Airfare Ceilings for Passengers of Economy Class Services for Domestic Commercial Airlines Transport, replaces the previous stipulation of the Minister of Transportation Regulation Number 14 of 2016 on Regulation of Minister of Transportation Number 14 of 2016 on the Formulation Mechanism for Calculating and Determining the Price Floor and Airfare Ceilings for Passengers of Economy Class Services for Domestic Scheduled Commercial Air Transportation. Regulations regarding the prices and tariffs are then regulated in the Decree of the Minister of Transportation Number 72 of 2019 on Airfare Ceilings for Passengers of Economy Class Services for Domestic Commercial Airlines.

Concerning the regulation, KPPU once again criticized and advised the Ministry of Transportation to reconsider the enactment of the price floor policy for airplane tickets that ICC assessed as potentially violating Law Number 5 of 1999 on Prohibition Monopolistic Practices and Unfair Competition (Kppu.go.id). The criticism was also raised by the National Consumer Protection Agency (BPKN), considering that the airline's floor and ceiling price fare policies were not following the rules in Law Number 8 of 1999 on Consumer Protection (Anggit, 2019).

Table.1 Price Control Policies in Various Sectors in Indonesian Laws and Regulations

\section{Sectors of Industry}

Public Transportation

Online Ride-Sharing

Airfare

\section{Laws and Regulations}

Regulation of the Minister of Transportation Number PM 36 of 2016 on Basic Tariffs, Upper Limits, and Lower limits Tariffs for Intercity, Inter-Province, Economy Class Passenger Transportation on the Road by Public Bus Car Decree of the Minister of Transportation Number KP 348 of 2019 on Guidelines for Calculating Service Cost for Using Motorcycles Used for Public Interests Conducted By An Applications

Regulation of the Minister of Transportation Number 20 of 2019, regulating the Procedure and Formulation for the Calculation of Airfare Ceilings for Passengers of Economy Class Services for Domestic Commercial Airlines Transport replacing the previous stipulation of the Minister of Transportation Regulation Number 14 of 2016 on the Formulation Mechanism for Calculating and Determining the Price Floor and Airfare Ceilings for Passengers of Economy Class Services for Domestic Scheduled Commercial Air Transportation

Decree of the Minister of Transportation Number 72 of 2019 on Airfare Ceilings for Passengers of Economy Class Services for Domestic Commercial Airlines

Telecommunication

Based on Table.1 all the criticisms raised against these rules are attributed to consumers because every activity (such as business, trade, etc.) that interacts with consumers must prioritize consumers' interests. Hence, every rule (in this case, price control) is related to consumer protection (Mehta, 2018). On the other hand, price control has been debated by several parties and has been controversial for a long time because it indicated the government's efforts to intervene, regulate and control the price. It has also long been a standard topic for the economist. Hence, since Adam Smith's era, one question is, "Are specific prices so special that government controlling them is justified?"

In this study, the authors will analyze the policies or rules related to the Indonesian government's price control through several laws and regulations. The authors will analyze each 
dimension of price control related to welfare through an economic approach: the antimonopoly law's goal. This search will provide insights on more effective regulation (especially in pricing policies) to the country's ideal.

\section{RESEARCH METHOD}

This study used a critical literature review method. A critical literature review is an objective, thorough summary of evaluation and synthesis of information and critical analysis of available relevant literature on the topic being discussed (Nuruddeen, 2015). This type of review often requires more creative data sets, as the aim is usually to cover all published articles on the topic and combine perspectives and insights from different fields of research traditions (Snyder, 2019).

This study's data were taken from primary data sources such as laws and regulations and secondary data from books, journals, and articles. The data were then collected by collecting literature reviews and then analyzed using a critical analysis of the literature to identify strengths and weaknesses and deficiencies or contradictions between literature sources (Torraco, 2016).

\section{RESULT AND DISCUSSION}

\section{The Advantages and Disadvantages of Price Control}

The main issue in pricing activity is when the government intervenes by setting and controlling prices and creating its limitations. At first, the basic idea of price controls is that if specific free movements (unregulated) of prices result in dire consequences, or if it makes some essential national goals challenging to be achieved, it is legal to keep an eye on these prices and ultimately to make the situation better (Laguerodie \& Vergara, 2008). However, as time goes by, the price control regulation has been controversial and created pros and cons in many arguments and discussions due to the positive (advantages) and negative (disadvantages) impacts of the regulation (Vernon et al., 2006).

Microeconomically, pricing control enables business actors or manufacturers to confirm underlying production costs (Myers \& Harvey, 2001). Price control also has the advantage that it goes beyond that. According to Article 71 Law Number 11 of 2020 on Work Creation which regulates amendments to Law Number 36 of 1999 concerning Telecommunications wherein the amendment to Article 28 of the Telecommunications Law states that price control is made in protecting the interests of the community and creating fair business competition. Some scholars also noted the advantages of price control where price control is needed to maintain and ensure that prices in the market remain within reasonable limits (Normal) (Reveley, 2012). Even in some cases and reasons, price control aims to create public order and prevent public unrest by controlling essential commodities' prices (Corradi, 2018).

Experts reveal many distortion effects (Deo et al., 2020). Thus, most economists' instinctive reaction to price control is harmful and will result in nothing but shortages and misallocation of resources and trigger black markets and high transaction costs (Ghosh \& Whalley, 2004) and illegal economic practice (Coyne \& Coyne, 2015).

Over the past twenty years, many countries have tried to implement it. Instead of expecting to control the price level, it does not have an adequate effect, either on microeconomics or macroeconomics (Kenyon, 2013). Some believe that price controls damage the market by preventing an increase in the supply of products from meeting demand. This rule would only lead to significant welfare losses, lower product quality, reduced investment, and higher prices in the long run (Coyne \& Coyne, 2015). Some others think that price control is a rule established by the government that will only suspend individual rights (both business actors and consumers), impose a fair legal system, and impose arbitrary bureaucratic control over people's lives (Carr, 1976). It is also a form of legislative action that disrupts private contracts in the market, causing changes in the quality of goods being transacted or eliminates the existing transaction. It makes trading stop and causes the market to be clean (Cheung, 1974). 
Table.2 Overall Advantages and Disadvantages of Price Control

\begin{tabular}{|c|c|c|c|}
\hline \multicolumn{4}{|c|}{ Price Control } \\
\hline & & $\begin{array}{c}\text { Sources } \\
\end{array}$ & Affected Parties \\
\hline \multirow{5}{*}{$\begin{array}{c}\text { Overall } \\
\text { Advantages }\end{array}$} & $\begin{array}{l}\text { Protecting the interests of the } \\
\text { community }\end{array}$ & $\begin{array}{l}\text { Law Number } 11 \text { of } 2020 \\
\text { on Work Creation }\end{array}$ & $\begin{array}{l}\text { Consumers or } \\
\text { Community }\end{array}$ \\
\hline & Creating fair business competition & $\begin{array}{l}\text { Law Number } 11 \text { of } 2020 \\
\text { on Work Creation }\end{array}$ & Business Actors \\
\hline & $\begin{array}{l}\text { Maintaining and ensuring that } \\
\text { prices in the market remain } \\
\text { within reasonable limits (Normal) }\end{array}$ & (Reveley, 2012) & $\begin{array}{l}\text { Consumer and } \\
\text { Business Actors }\end{array}$ \\
\hline & Preventing public unrest & (Corradi, 2018) & State \\
\hline & $\begin{array}{l}\text { Enabling business actors or } \\
\text { manufacturers to confirm the } \\
\text { coverage of underlying production } \\
\text { costs }\end{array}$ & (Myers \& Harvey, 2001) & $\begin{array}{l}\text { Business actors or } \\
\text { Manufacturers }\end{array}$ \\
\hline \multirow{8}{*}{$\begin{array}{c}\text { Overall } \\
\text { Disadvantages }\end{array}$} & $\begin{array}{l}\text { Triggering black markets and high } \\
\text { transaction costs }\end{array}$ & (Ghosh \& Whalley, 2004) & $\begin{array}{l}\text { State } \\
\text { Consumers }\end{array}$ \\
\hline & $\begin{array}{lll}\begin{array}{l}\text { Triggering } \\
\text { practice }\end{array} & \text { illegal } & \text { economic } \\
\end{array}$ & (Coyne \& Coyne, 2015) & State \\
\hline & $\begin{array}{l}\text { losing welfare, lowering product } \\
\text { quality, creating higher prices }\end{array}$ & $\begin{array}{l}\text { (Coyne \& Coyne,2015) and } \\
\text { (Cheung, 1974) }\end{array}$ & Consumers \\
\hline & suspending individual rights & (Carr, 1976) & $\begin{array}{l}\text { Business actors } \\
\text { and Consumers }\end{array}$ \\
\hline & $\begin{array}{l}\text { Imposing arbitrary bureaucratic } \\
\text { control over people's lives }\end{array}$ & (Carr, 1976) & $\begin{array}{l}\text { Business actors } \\
\text { and Consumers }\end{array}$ \\
\hline & $\begin{array}{l}\text { Disrupting private contracts in the } \\
\text { market }\end{array}$ & (Cheung, 1974) & $\begin{array}{l}\text { Consumers and } \\
\text { Business Actors }\end{array}$ \\
\hline & Cleaning the Market & (Cheung, 1974) & $\begin{array}{l}\text { Consumers and } \\
\text { Business Actors }\end{array}$ \\
\hline & $\begin{array}{l}\text { Distorting markets and } \\
\text { consequently harming economic } \\
\text { growth and poverty reduction }\end{array}$ & $\begin{array}{l}(\text { Cerda et al,2020), } \\
\text { (Guenette, 2020) } \\
\text { (Mehta, 2018) }\end{array}$ & $\begin{array}{l}\text { Business Actors } \\
\text { and Consumers }\end{array}$ \\
\hline
\end{tabular}

Based on the Table.2 the price control, which interprets its effects, economic behavior, and limits, is still relatively rigid (Cheung, 1974) and has been used in developed countries with social intentions. As a result, this policy often distorts markets and negatively impacts economic growth and poverty reduction (Cerda et al., 2020; Guenette, 2020; Mehta, 2018). If the state aims and expects to create fair competition, improving the competitive environment can be more practical than price control. Carefully designed and properly enforced antimonopoly laws that involve consumer protection laws are an essential component of an institutional framework that supports market mechanisms. A robust legal and regulatory framework that supports competitive markets provides a more effective response to many issues than price controls (Guenette, 2020). In short, price control should not be used as a rule or regulation to create fair competition.

\section{The Urgency of Price Control}

If indeed price control is intended to create a fair business as stipulated in Law No.11 of 2020 , this is a precious objective. Since 'Fair Competition' is not only a legal concept, it is also an important ethical concept. This term refers to what companies are legally and ethically required to fulfill in their internal and external business relationships. Even so, policymakers should not ignore aspects of consumer protection, interests, and welfare. Because in the antimonopoly law, consumer protection (Moisejevas \& Novosad, 2013) or welfare (Colombo, 2011; Easterbrook, 1981) is one of the main objectives as stipulated in article 2 of Law number 5 of 1999 on Prohibition of Monopolistic Practices and Unfair Business Competition. Modern economic theory has also explicitly stated that a policy must promote consumer welfare because efficiency alone is insufficient (Mateus, 2011). 


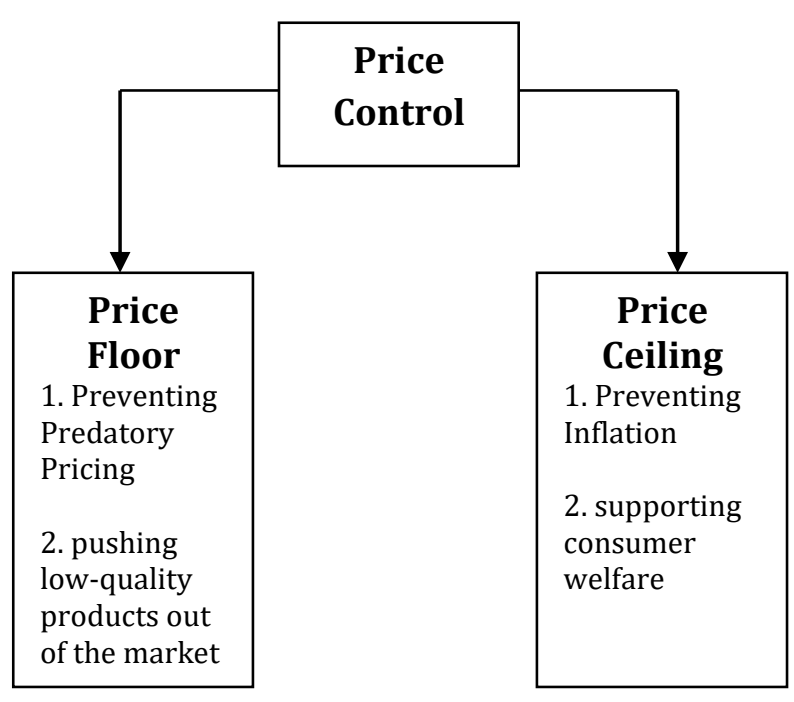

Figure.1 The Form of Price Control Source: $($ Sinha, 2000)

Figure.1 As the price control included price floor and ceiling (Sinha, 2000), the authors realize the bad possibilities if the state does not control prices through law. First, setting prices too low will only lead to predatory pricing practices and push low-quality products out of the market (Bilotkach, 2014; Sinha, 2000). Therefore, rules related to the price floor are necessary. Second, the absence of regulations related to price control will result in inflation because the market pricing is too high, triggering an increase in inflation. Therefore, a regulation regarding the price ceiling is needed to avoid the adverse effects of inflation.

\section{Price Floor}

Floor pricing, as the name implies, is a rule that establishes the minimum price charged by the company for the products or services it offers. In general, an efficient base price should be set at a level that reflects all the firm's resource costs in producing a product or service (Weisman, 2002). Based on the existing literature, it is common to regulate base prices in various industries, with the main economic reason for setting the base price is to prevent predatory pricing or anti-competitive price pressures (Sinha, 2000; Weisman, 2002).

Based on Article 20 of Law Number 5 of 1999, "business actors are prohibited from supplying goods and or services utilizing selling at a loss or setting meager prices with the intention of getting rid of shutting down the business of their competitors in relevant market so that it may result in monopolistic practices and or unfair business competition".

Predatory pricing has become a classic problem in antitrust, competition, as well as antimonopoly law enforcement. Like other competition regulation areas, successful enforcement requires the right action to identify and prevent anti-competitive behavior without hindering good behavior in the process. However, predatory price cuts are tough to distinguish from intense competition. Courts that prohibit specific price cuts unreasonably can freeze behavior (Scott Hemphill, 2001). For that reason, predatory pricing has been debated by some experts and is considered a paradoxical offense. The "predator" was accused of charging too low as a good move but overreaching. The law's role is likely to influence the perception of most people who consider predation socially dangerous because current artificially low prices exclude competitors and allow future high prices (Crane, 2005).

Predatory pricing occurs when a company sets the price of its products below the market price and competitors with which the company sacrifices temporary income in the short term to make its competitors out of business or unable to enter (barriers to entry). Once the target has been eliminated, the presumed predator then raises its price to a high "supracompetitive" level and generates a high profit to "recoup" the previously lost income. By eliminating competitors in the short term and sacrificing profits to do so, the alleged predator hopes to reduce

26 | Zaid', Farouk Aisha Dawaki', Sabit Kazeem Ololade ${ }^{3}$ 
competition in the long run. Such a reduction in competition would theoretically allow the predatory guess not only to recover all lost revenue but also make higher-than-possible profits before the competition was reduced (Funk \& Jaag, 2018; Sheffet, 1994).

Based on the explanation, the predatory pricing strategy has two stages strategy (1) setting low or lower prices to force competitors out, blocking the entry of competitors (barriers to entry), and in turn (2) getting a monopoly position and using the market power obtained to raising the old price is enough to cover the losses of the first stage (Tumlinson, 2016). Does predatory pricing like what they said? Is it harmful so that it must be considered as something illegal and requires the government to make rules on predatory pricing prohibition? This article is about to discuss it step by step.

\section{First, setting a low or lower price}

The term "selling at a loss" as what is mentioned in the law this is because refers to the sale of products or services below cost (Colombo, 2011; Peltier et al., 2013) or average variable cost (AVC) (Areeda \& Turner, 1975; Behringer \& Filistrucchi, 2015). Thus, the price set is shallow and definitely below the competitors' prices (Durrance, 2012).

The predatory pricing rule is the most vulnerable of all existing legal theories and challenges to competition law because it involves attempting to punish behavior that would typically be considered a virtue by offering low or even meager prices (Crane, 2005). Also, predatory price is considered a complicated problem to solve in competition law because the reduction in predatory prices is difficult to prove and distinguish from other intense competition (Santoso, 2018; Scott Hemphill, 2001). It is inseparable from the complexity of finding the right benchmark to set a competitive or fair price (Corradi, 2018). Therefore, regulatory authorities, law enforcement, and supervisors need to be very vigilant and thorough in detecting any kind of anti-competitive behavior. Moreover, they may have clashes of opinion and confuse the legal domain (Mishra \& Rao, 2015).

Price reductions, selective or not, and various non-price competitive strategies (such as advertising and innovation) are an integral part of the ordinary competitive market process and strategy. This process serves an essential social purpose. This strategy serves to find products and services that consumers and business organizations like to provide these products and services (Armentano, 1989). It is a public secret that the way to make consumers delight is to offer them goods and services at lower prices (James, 1935). Consumers who buy from predators at low prices are not harmed, and they greatly benefit from predation (Easterbrook, 1981; Elzinga \& Hay, 2020). Low prices can only be bad for consumers in the long run and charge high monopolistic prices (Elzinga \& Hay, 2020; Scott Hemphill, 2001). As long as there is no possibility or evidence that the company will make a recoupment, it is not harmful.

\section{Second, forcing competitors out and barriers to entry}

Predatory pricing is often interpreted and seen as the act of pricing below a competitor's cost to drive a competitor out of the market (Durrance, 2012) and create a barrier to entry into the market for potential new competitors (Kaplow, 2018; Prado et al., 2010). Thus, many consider that predation can be used to create so-called behavioral or strategic barriers to entry. Competitors will leave, and potential participants will refuse to enter if predatory behavior makes them hope that their attempts to compete will prove unfavorable because of the anticipated predatory price (Kaplow, 2018). These assumptions and arguments essentially make many economists and industrial organizations argue that predatory pricing is irrational and rarely observed. The argument is that pricing below cost to push a competitor out of the market would be irrational for two reasons: (1) there are more profitable ways (e.g., merger and acquisitions) to eliminate competitors, and (2) future price increases will result in new entries (Gomez et al., 2008).

Without denying, low price is undoubtedly useful in winning over competitors, but it is not a crime either because, at the same time, it represents a symbol of consumer profit (surplus) (Elzinga \& Hay, 2020). Posner (1976) argues that predatory pricing should not be considered a practice that barrier the entry of new competitors, most likely to delay and not even for a long 
time (Harrison, 1988). Even if the predators successfully shut down or drive all competitors out, They will not dare increase their price, lest new competitors enter the market. Predatory pricing will not damage long-term consumer interests because long-term consumer interests are protected by preventing predators from disposing of goods (McGee, 2008).

One of the most recent predation studies that are not always the behavior of price reduction, but considered a predatory action, will immediately drive out and prevent competitors from entering. (Genesove \& Mullin, 2006) have found evidence that the American Sugar Refining Company (ASRC) is pursuing a predatory pricing strategy and preying on its competitors, thus making ASRC labeled a "despicable predator" of influencing rivals, lowering the acquisition price of small entrants and incumbents. However, the ASRC failed to block entry significantly and needed to accommodate the big competitors that had emerged.

Even if it is possible (that predatory practice can shut down the competitors and prevent competitors from entering), according to Easterbrook (1981), it still refers to business competition law designed to maximize welfare by protecting competition, not competitors. Therefore, every competition strategy and practice that injures competitors do not fall within the scope of business competition law issues unless they also reduce consumer welfare. In any economy, price, quantity, and output always fluctuate and adjust to external and internal conditions. Companies planning to anticipate market changes or guard against risks may reduce their costs to survive and compete with competitors. These are natural and desirable in business and competition, regardless of the possible adverse impact on some companies and their owners.

\section{Third, leading a monopoly position and using the market power obtained to raise the old price}

One of the reasons for Law No. 5 of 1999 prohibits predatory pricing practice because it can lead to monopolistic practice. It is even further strengthened by the large amount of literature that agrees with the law that punishing predatory prices is the worst illegal open exploitation because the strategy is using the economic justification for getting an attempt to monopolize (Kennedy, 2020; Taylor et al., 2013) after the market is 'cleared' (Mazzone \& Mingardi, 2011). For jurists or legal scholars and some other economists who argue that predatory pricing is rational, they also note that predatory pricing will only make sense if predatory firms compensate for their initial losses after gaining monopoly power. In the end, it is the consumer who becomes the victim because when the predation is successful, the predator will increase output insufficiently to compensate for the loss of output as a result of the loss of its competitors and then increase the price. If so, it will undoubtedly be a threat to consumers (Barnett et al., 2007).

It seems that the theory and rules regarding the prohibition of predatory pricing always have a point of justification for it. Therefore, economists often argue that the practice of predatory pricing is irrational and rare for some points:

First, there are cheaper or more specific ways to obtain or maintain a monopoly than sacrifice many initial costs (Milgrom \& Roberts, 1982). Second, this condition makes little sense if used to achieve a monopoly position because other ways are more effective and, in some cases, let alone get a monopoly position, even to survive in the market often fails. As happened to Uber in Indonesia, which set cheap prices under Grab and Gojek, it fell and lost its competitors. On the contrary, predatory pricing might be useful and makes sense if implemented by companies in a monopoly market, as (Posner, 2009) argues that predatory pricing is only a means or method to maintain (not to get) a monopoly market.

Third, predation is not the only thing that can get a monopoly position. Even non-price factors and high prices could be useful in gaining the position as was the case with the National Cash Register Co. (NCR) non-price, which allows it to consolidate and maintain a monopoly persuades customers to buy durable goods at high prices and high profits (Brevoort \& Marvel, 2004). Fourth, even for economists who argued that the predatory price is rational, it must be required if the predatory actor is compensated after his victory. Unfortunately, it cannot be guaranteed. If the firm succeeds in driving out all other competition through predatory pricing,

28 | Zaid', Farouk Aisha Dawaki', Sabit Kazeem Ololade ${ }^{3}$ 
it does not mean that it will increase the prices after that (Anderson, 2003). Suppose that the predatory firm raises its price above the average price after successfully driving out its competitors from the market. The increased price will create an attraction for new competitors. So, apart from the absence of barriers to entry, victory in a price war is nothing but useless because the winning firm must keep prices close to competitive levels if they are not to risk the entry of potential competitors (Brooks, 1961).

Hence, predatory pricing without a reasonable prospect of recovery will be irrational, so it will not happen. If a company tries to charge a lower price to harm or even damage their competitor predominantly, they will suffer losses and never compensate for it. As soon as they try to charge a higher price, later on, new firms will enter. Therefore, it is doubtless that even successful predators will not enjoy their victories for long because new competition will inevitably and quickly erode the market forces they may have conquered (Giocoli, 2014).

Based on the explanation above, there is not enough reason for antitrust laws or courts to take predation seriously (Easterbrook, 1981). Therefore, the government has no urgency to limit or even prohibit predatory pricing practices legally, both compelling and regulatory laws (Armentano, 1989). Predation is not a crime. If there is predation in pricing, it must be classified as a victimless crime because no one's rights are violated (Fisher, 1987). Because the predation actors are not fraudulent, the seller may be completely transparent about prices and even intentions. There is no coercion in predatory prices. Even predatory prices can be agreed upon by buyers and sellers without threats or use of force, some parties are neither forced nor threatened in conducting transactions.

On the other hand, it is precisely the existence of a competition policy that punishes predatory pricing practices made by the government either by law or other regulation which reduces consumer welfare because the regulation is tantamount to preventing consumers from determining the structure of market supply they expect (Armentano, 1989). In the end, price controls are a more dangerous solution than predatory price cuts. Therefore, it has become the National Consumer Protection Agency's attention (BPKN) to naturally assess that the tariff control policy (price), especially for the price floor, has violated consumers' rights.

\section{Price Ceiling}

The setting of price or tariff ceiling has been widely adopted and an essential feature of many countries' economic environment, especially for meeting basic needs (Huizinga, 1995). It is also a common direct market control in many market economies (Kim \& Yoo, 2007). Hence, many countries' setting of price ceilings is also commonly used to stabilize market prices. It also serves as a focal point to facilitate price coordination across multiple markets (Zhang et al., 2020).

Price ceiling has been discussed and debated in many pieces of literature. Engelmann \& Müller (2011) the effect of a price ceiling is harmful and can weaken competition because they can serve as collusive focal points for pricing decisions. Although controversial, the rule of price ceiling has been used in various markets because it can serve as a tool to correct inefficiencies stemming from inadequate competition, while another reason is to protect consumers' welfare (Bennett \& Chioveanu, 2019).

\section{Price Ceiling and Consumer Welfare}

Price ceiling has been used extensively in the utility market, where competitive pricing is usually restricted, to secure low prices for consumers (Bennett \& Chioveanu, 2019). So, when consumers pay for a good or service at a lower price, of course, this will increase the consumer surplus, which in turn leads to consumer welfare as defined by Bork (1978) as the ability of consumers to fulfill their needs and fully satisfy their desires at a price they can afford. Thus, the price ceiling rule is needed to assist in safeguarding consumer welfare by preventing the exorbitant costs associated with price increases due to volatility or aggressive reduction targets (Perkis et al., 2016; Roques \& Savva, 2009).

The high price caused by rising prices is the biggest threat to consumer welfare. Even those who criticize that predatory pricing is reasonable also argue that the threat is not low 
prices but high prices after obtaining a monopoly position as a recoupment form (Cheng, 2020). Significant price increases result in a loss of real income and consumer purchasing power in all countries (Aftab et al., 2017). The welfare losses caused by price increases are more significant than the welfare gains caused by falling prices (Bellemare, 2015). So this is where the role of setting the upper limit tariff is needed to protect the sharp, high price (Mckibbin et al., 2014) and secure low prices for consumers (Bennett \& Chioveanu, 2019). Therefore, the regulation regarding the price ceiling is believed to increase consumer surplus (Braido \& Ledo, 2018) and affect welfare under certain conditions (Rauh, 2004). The price ceiling limits a seller's maximum price and affects its bargaining power (Kujal, 1999).

When costs are high, this situation leads to a much higher equilibrium price, in which case a price ceiling is more necessary than a price floor. Suppose the company charges a high price close to the price ceiling. The intensity of demand then decreases as most consumers soon discover that this will lead to a welfare loss. Purchase intensity also decreases because most consumers will try to find and prefer prices below their price. Hence, the ceiling cost rule can increase welfare and control the market's size (McCarthy, 2009). However, to further maximize welfare, the price ceiling setting must be close to and not too high from its marginal cost (Earle et al., 2007). There is no doubt that high prices endanger consumers' welfare and threaten the country's economy. Besides protecting consumers, the price ceiling is also to protect the country's economy (Bennett \& Chioveanu, 2019; Edlin, 2010).

\section{Price Ceiling to Reduce and Prevent Inflation}

Inflation is defined as a continuous increase in the general level of prices for goods and services. The price index increase is broad inflation representing the overall level of prices for goods and services. A broad price index is often measured by the Consumer Price Index (CPI), the Personal Consumption Expenditures Price Index (PCEPI) and the GDP deflator. In addition to a broad price index, inflation can also be measured by a narrow price index in specific economic sectors such as the Reuters-CRB Index (CCI), Producer Price Index, and Employment Cost Index (ECI) (Yesikar et al., 2015).

Inflation has always been a matter of concern and considered dangerous because inflation plays a significant role in weakening the economy. Not only that, high inflation can cause people's confidence in their currency and economy to decline and can make it less attractive for foreign investors to invest in the country concerned. Therefore, high inflation often hurts economic growth (Shah et al., 2019). Inflation can also cause foreign exchange or foreign currency to increase, which will affect (increase) prices (Pagliacci, 2020).

Purwono et al. (2020) argue that inflation can not be separated from two harmful effects in the form of instability in the country's economy and the people's welfare. Economic instability is characterized by price increases over the prices of goods and services in general in a country. The increase is not an exception to the increase in the price of general commodities that ordinary people must use in their daily life which will then have an impact on people's purchasing power so that people's welfare can be reduced (Purwono et al., 2020; Shah et al., 2019).

Moreover, the effect of inflation will further exacerbate poor people, orphans, low incomes, job losses, and where they have to pay higher prices for necessities (Jaravel, 2019; Shah et al., 2019; Tyner \& Gershenson, 2020). Therefore, the government, strategists, and policymakers must think more about and act on how to prevent and reduce inflation. And this is where price control is needed to avoid the destructive effects of inflation because inflation is an expression of an inadequate profit which must be balanced with price and money control policies (Mattick, 2016). The price ceiling has become a policy to test inflation control. Controlling and preventing inflation will be considered successful when the market price is sometimes below the price ceiling (Galbraith, 1952). Besides preventing, the price ceiling is also trusted and used by many countries to overcome high inflation (Aparicio \& Cavallo, 2019). Adopting any price control should take more fundamental steps to overcome inflation (Phillips, $\underline{1955)}$. 
Of course, some oppose and disagree with price controls. They expect their income to rise faster and higher than the price of the goods and services they buy, thus improving their situation and increasing demand for them. They do not realize that such benefits are always temporary. Sellers of goods and services whose prices have not immediately risen will be well aware of this fact. Soon they will raise the prices of their goods and services to the point where they enjoy a profit. This situation only leads to more increases in price (Becker, 1942).

\section{CONCLUSION}

Pricing is part of a strategy that is inseparable from the competitive market process. The price game is a legitimate competitive strategy and not illegal, like other legal competition strategies. So, the government's control of prices is a legislative action that destroys the freedom of market activities that counter-competitive and tends not to protect competition; somewhat, it limits competition. Moreover, some economists view price controls' negative impact from restricting behavior in the market to encouraging black markets and other illegal economic activities. Thus, there is no urgency in intervening by imposing price or tariff restrictions by the government.

Unless any form of competition, both price and non-price, has led to unfair competition, namely competition that can harm and endanger national economic stability and welfare. So, state intervention is needed to take preventive action against this behavior in situations and conditions. In the case of a price cap, the government must set a tariff or price ceiling in order not only to maintain consumer welfare but also to prevent inflation from occurring, which could endanger the country's economy.

Meanwhile, if the competitive strategy (pricing) does not endanger consumers' welfare, it favors consumers' welfare, supporting social welfare in general. There is no right or urgency for the government to make rules prohibiting such actions. One of them is the regulation related to the setting of tariffs or lower limit prices by which the government through these regulations either directly or indirectly endangers the welfare of consumers and prevents consumers from determining their preferred market supply structure.

\section{REFERENCES}

Aftab, S., Yaseen, M. R., \& Anwar, S. (2017). Impact of rising food prices on consumer welfare in the most populous countries of South Asia. International Journal of Social Economics, 44(8), 1062-1077. https://doi.org/10.1108/IJSE-01-2016-0016

Anderson, W. L. (2003). Pounding square pegs into round holes: Another look at the neoclassical theory of predatory pricing. The Quarterly Journal of Austrian Economics, 6(1), 23-40. https://doi.org/10.1007/s12113-003-1011-5

Anggit, I. (2019, April). "Cabut Kebijakan Tarif Batas Bawah Pesawat!" https://www.cnbcindonesia.com/news/20190408145725-4-65205/cabut-kebijakantarif-batas-bawah-pesawat

Aparicio, D., \& Cavallo, A. (2019). Targeted Price Controls on Supermarket Products. The Review of Economics and Statistics, 1-41. https://doi.org/10.1162/rest_a_00880

Areeda, P., \& Turner, D. F. (1975). Predatory Pricing and Related Practices under Section 2 of the Sherman Act. Harvard Law Review, 88(4), 697. https://doi.org/10.2307/1340237

Armentano, D. T. (1989). Antitrust reform: Predatory practices and the competitive process. The Review of Austrian Economics, 3(1), 61-74. https://doi.org/10.1007/BF01539558

Barnett, W., Saliba, M., \& Block, W. (2007). Predatory pricing. Corporate Ownership and Control, 4(4 D), 397-402. https://doi.org/10.22495/cocv4i4c3p4

Becker, H. A. (1942). One Million Votes for Price Control. The Clearing House: A Journal of Educational Strategies, Issues and Ideas, 16(5), 262-264. https://doi.org/10.1080/00098655.1942.11473189

Behringer, S., \& Filistrucchi, L. (2015). Areeda-Turner in Two-Sided Markets. Review of 
Industrial Organization, 46(3), 287-306. https://doi.org/10.1007/s11151-015-9460-5

Bellemare, M. F. (2015). Rising food prices, food price volatility, and social unrest. American Journal of Agricultural Economics, 97(1), 1-21. https://doi.org/10.1093/ajae/aau038

Bennett, J., \& Chioveanu, I. (2019). Pro-Consumer Price Ceilings under Regulatory Uncertainty. Scandinavian Journal of Economics, 121(4), 1757-1784. https://doi.org/10.1111/sjoe.12298

Bilotkach, V. (2014). Price floors and quality choice. Bulletin of Economic Research, 66(3), 231245. https://doi.org/10.1111/j.1467-8586.2011.00422.x

Bork, R. . (1978). The Antitrust Paradox: A Policy At War With Itself. New York: Basic Book.

Braido, L. H. B., \& Ledo, B. C. A. (2018). Dynamic price competition in auto insurance brokerage. RAND Journal of Economics, 49(4), 914-935. https://doi.org/10.1111/1756-2171.12256

Brevoort, K., \& Marvel, H. P. (2004). Successful Monopolization Through Predation: The National Cash Register Company. In Research in Law and Economics (Vol. 21, pp. 85-125). Emerald Group Publishing Limited. https://doi.org/10.1016/S0193-5895(04)21003-X

Brooks, R. C. (1961). Price Cutting and Monopoly Power. Journal of Marketing, 25(5), 44-49. https://doi.org/10.1177/002224296102500508

Carr, J. (1976). Wage And Price Controls: Panacea For Inflation Or Prescription For Disaster? The Fraser Institute.

Cerda, R., Silva, A., \& Lüders, R. (2020). Price controls, hyperinflation, and the inflation-relative price variability relationship. Empirical Economics. https://doi.org/10.1007/s00181-02001953-w

Cheng, H. F. G. (2020). An economic perspective on the inherent plausibility and frequency of predatory pricing: the case for more aggressive regulation. European Competition Journal, 16(2-3), 343-367. https://doi.org/10.1080/17441056.2020.1770478

Cheung, S. N. . (1974). A Theory of Price Control. Journal of Law and Economics, 17(1), 53-71.

Colombo, S. (2011). Taxation and predatory prices in a spatial model. Papers in Regional Science, 90(3), 603-612. https://doi.org/10.1111/j.1435-5957.2010.00342.x

Corradi, M. C. (2018). Notes on competition and justum pretium theory and practice in medieval Italy: Lessons for modern EU competition price theory? Antitrust Bulletin, 63(3), 330-349. https://doi.org/10.1177/0003603X18780558

Coyne, C. J., \& Coyne, R. (2015). Flaws and Ceilings Price Controls and the Damage They Cause. Institute of Economic Affairs.

Crane, D. A. (2005). The Paradox Of Predatory Pricing. Cornell Law Review, 91(1), 1-66.

Deo, S., Tyagi, H., Chatterjee, C., \& Molakapuri, H. (2020). Did India's price control policy for coronary stents create unintended consequences? Social Science and Medicine, 246, 112737. https://doi.org/10.1016/j.socscimed.2019.112737

Durrance, C. P. (2012). Proposed Standards for Identifying Predation: Williamson's Perspective and the Court. Antitrust Bulletin, 57(3), 663-678. https://doi.org/10.1177/0003603X1205700306

Earle, R., Schmedders, K., \& Tatur, T. (2007). On price caps under uncertainty. Review of Economic Studies, 74(1), 93-111. https://doi.org/10.1111/j.1467-937X.2007.00415.x

Easterbrook, F. H. (1981). Predatory Strategies and Counterstrategies. The University of Chicago Law Review, 48(2), 263-337. https://doi.org/10.2307/1599465

Edlin, A. . (2010). Predatory Pricing. UC Berkeley: Berkeley Program in Law and Economics, 1-48.

Elzinga, K. G., \& Hay, G. A. (2020). Documenting the Antitrust Revolution over Seven Editions of Kwoka and White. The Antitrust Bulletin, 65(4), 523-546. https://doi.org/10.1177/0003603X20950200 
Engelmann, D., \& Müller, W. (2011). Collusion through price ceilings? In search of a focal-point effect. Journal of Economic Behavior and Organization, 79(3), 291-302. https://doi.org/10.1016/j.jebo.2011.02.008

Fisher, F. M. (1987). On Predation and Victimless Crime. Antitrust Bulletin, 32, 85-92.

Funk, M., \& Jaag, C. (2018). THE MORE ECONOMIC APPROACH TO PREDATORY PRICING. Journal of Competition Law \& Economics, 14(2), 292-310. https://doi.org/10.1093/joclec/nhy008

Galbraith, J. K. (1952). A Theory of Pricee Control. Cambridge, Massachusetts: Harvard University Press.

Genesove, D., \& Mullin, W. P. (2006). Predation and its rate of return: The sugar industry, 18871914. In RAND Journal of Economics (Vol. 37, Issue 1, pp. 47-69). RAND. https://doi.org/10.1111/j.1756-2171.2006.tb00003.x

Ghosh, M., \& Whalley, J. (2004). Are price controls necessarily bad? The case of rice in Vietnam. Journal of Development Economics, 73(1), 215-232. https://doi.org/10.1016/j.jdeveco.2003.03.004

Giocoli, N. (2014). Predatory Pricing in Antitrust Law and Economics A historical perspective. Routledge.

Gomez, R., Goeree, J. K., \& Holt, C. A. (2008). Chapter 22 Predatory Pricing: Rare Like a Unicorn? In Handbook of Experimental Economics Results (Vol. 1, Issue C, pp. 178-184). https://doi.org/10.1016/S1574-0722(07)00022-4

Guenette, J. D. (2020). Price Controls: Good Intentions, Bad Outcomes. World Bank Policy Research Working Paper, 9212, 1-17.

Harrison, G. W. (1988). Predatory pricing in a multiple market experiment. A note. Journal of Economic Behavior and Organization, 9(4), 405-417. https://doi.org/10.1016/01672681(88)90019-4

Huizinga, H. (1995). The political economy of price ceilings for necessities. Journal of Development Economics, 47(2), 443-454. https://doi.org/10.1016/0304-3878(95)00019$\mathrm{M}$

Issetiabudi, D. E. (2017). KPPU \& Kemenhub Bahas Angkutan Umum - Ekonomi Bisnis.com. https://ekonomi.bisnis.com/read/20170329/98/641071/kppu-kemenhub-bahasangkutan-umum

James, C. C. (1935). The One-Price Policy and Cut-Throat Competition. American Marketing Journal, amj-2(3), 193-195. https://doi.org/10.1177/002224293500200311

Jaravel, X. (2019). The unequal gains from product innovations: Evidence from the U.S. Retail sector. Quarterly Journal of Economics, 134(2), 715-783. https://doi.org/10.1093/qje/qjy031

Kaplow, L. (2018). Recoupment and Predatory Pricing Analysis. Journal of Legal Analysis, 10, 46112. https://doi.org/10.1093/jla/lay003

Kennedy, P. (2020). Squeezing linkLine: Rethinking Recoupment in Price Squeeze Cases. American Business Law Journal, 57(2), 383-437. https://doi.org/10.1111/ablj.12165

Kenyon, P. (2013). Price Control, Investment and Resource Allocation. History of Economics Review, 57(1), 88-95. https://doi.org/10.1080/18386318.2013.11681249

Kim, S., \& Yoo, Y. H. (2007). Policies to reduce rent seeking in controlled markets. International Economic Journal, 21(1), 27-47. https://doi.org/10.1080/10168730601180853

Kujal, P. (1999). Price ceilings and firm-specific quantity restrictions in posted-offer markets. Information Economics and Policy, 11(4), 389-406. https://doi.org/10.1016/S01676245(99)00018-9

Laguerodie, S., \& Vergara, F. (2008). The theory of price controls: John Kenneth Galbraith's 
contribution. Review of Political Economy, 20(4), 569-593. https://doi.org/10.1080/09538250802308950

Law Number 11 of 2020 on Work Creation, (2020).

Mateus, A. M. (2011). Predatory Pricing: A Proposed Structured Rule of Reason. European Competition Journal, 7(2), 243-267. https://doi.org/10.5235/174410511797248261

Mattick, P. (2016). Economics, Politics and the Age of Inflation. New York: Routledge.

Maulandy. (2019, May 6). KPPU Nilai Kemenhub Tak Harus Atur Batas Bawah Tarif Ojek Online I merdeka.com. https://www.merdeka.com/uang/kppu-nilai-kemenhub-tak-harus-aturbatas-bawah-tarif-ojek-online.html

Mazzone, L., \& Mingardi, A. (2011). Innovation, competition and antitrust: An examination of the intel case. Economic Affairs, 31(2), 68-75. https://doi.org/10.1111/j.14680270.2011.02083.x

McCarthy, I. (2009). Simulating sequential search models with genetic algorithms: Analysis of price ceilings, taxes, advertising and welfare. Computational Economics, 34(3), 217-241. https://doi.org/10.1007/s10614-008-9164-0

McGee, R. W. (2008). Ethical aspects of using government to subvert competition: Antidumping laws as a case study of rent seeking activity. Journal of Business Ethics, 83(4), 759-771. https://doi.org/10.1007/s10551-008-9663-x

Mckibbin, W., Morris, A., \& Wilcoxen, P. (2014). A Proposal to Integrate Price Mechanisms into International Climate Negotiations. Asia and the Pacific Policy Studies, 1(3), 600-608. https://doi.org/10.1002/app5.55

Mehta, P. S. (2018). Economic regulations, competition, and consumer protection in ancient India. Antitrust Bulletin, 63(3), 316-329. https://doi.org/10.1177/0003603X18780557

Milgrom, P., \& Roberts, J. (1982). Predation, reputation, and entry deterrence. Journal of Economic Theory, 27(2), 280-312. https://doi.org/10.1016/0022-0531(82)90031-X

Mishra, A. K., \& Rao, G. (2015). Analysing Anti-competitive Behaviour: The Case for Indian Telecom Industry. Science, Technology and Society, 20(1), 21-43. https://doi.org/10.1177/0971721814561395

Moisejevas, R., \& Novosad, A. (2013). Some Thoughts Concerning the Main Goals of Competition Law. Jurisprudence, 20(2), 627-642. https://doi.org/10.13165/jur-13-20-2-14

Myers, M. B., \& Harvey, M. (2001). The value of pricing control in export channels: A governance perspective. Journal of International Marketing, 9(4), 1-29. https://doi.org/10.1509/jimk.9.4.1.19941

Nuruddeen, M. (2015). The Legal Critical Literature Review. UUM Journal of Legal Studies, 6(1), 13-32. https://doi.org/10.32890/uumjls.6.2015.4585

Pagliacci, C. (2020). Financial constraints and inflation in Latin America: The impacts of bond financing and depreciations on supply inflation. Economic Analysis and Policy, 68, 379-397. https://doi.org/10.1016/j.eap.2020.10.006

Peltier, J. W., Skidmore, M., \& Milne, G. R. (2013). Assessing the impact of gasoline sales-belowcost laws on retail price and market structure: Implications for consumer welfare. Journal of Public Policy and Marketing, 32(2), 239-254. https://doi.org/10.1509/jppm.12.129

Perkis, D. F., Cason, T. N., \& Tyner, W. E. (2016). An Experimental Investigation of Hard and Soft Price Ceilings in Emissions Permit Markets. Environmental and Resource Economics, 63(4), 703-718. https://doi.org/10.1007/s10640-014-9810-z

Phillips, C. F. (1955). Administrative Price Control. Journal of Marketing, 19(4), 353-353. https://doi.org/10.1177/002224295501900408

Posner, R. A. (1976). Antitrust Law: An Economic Perspective. Chicago University Press. 
Posner, R. A. (2009). Antitrust Law. Chicago University Press.

Prado, A. S., Parada, F., \& Andrades, P. (2010). Predatory pricing in plastic surgery. In Plastic and Reconstructive Surgery (Vol. 125, Issue 2, p. 91e). https://doi.org/10.1097/PRS.0b013e3181c87aff

Purwono, R., Yasin, M. Z., \& Mubin, M. K. (2020). Explaining regional inflation programmes in Indonesia: Does inflation rate converge? Economic Change and Restructuring, 53(4), 571590. https://doi.org/10.1007/s10644-020-09264-x

Rauh, M. T. (2004). Wage and price controls in the equilibrium sequential search model. $\begin{array}{llll}\text { European } \quad \text { Economic } & \text { Review, }\end{array}$ https://doi.org/10.1016/j.euroecorev.2004.03.001

Reveley, J. (2012). Wartime Price Control and Maritime Industry Corporatism: The Case of New Zealand Coastal Shipping. International Journal of Maritime History, 24(2), 181-200. https://doi.org/10.1177/084387141202400208

Roques, F. A., \& Savva, N. (2009). Investment under uncertainty with price ceilings in oligopolies. Journal of Economic Dynamics and Control, 33(2), 507-524. https://doi.org/10.1016/j.jedc.2008.07.002

Santoso, B. (2018). Predatory Pricing in the Telecommunication Business Advertisement in Indonesia. IOP Conference Series: Earth and Environmental Science, 175(1), 012184. https://doi.org/10.1088/1755-1315/175/1/012184

Scott Hemphill, C. (2001). The Role of Recoupment in Predatory Pricing Analyses. Stanford Law Review, 53(6), 1581. https://doi.org/10.2307/1229551

Shah, I. A., Agarwal, M. L., \& Kundu, S. (2019). Welfare Cost of Inflation: Evidence from India. Journal of Quantitative Economics, 17(4), 781-799. https://doi.org/10.1007/s40953-0180140-9

Sheffet, M. J. (1994). The Supreme Court and Predatory Pricing. Journal of Public Policy \& Marketing, 13(1), 163-167. https://doi.org/10.1177/074391569401300116

Sinha, S. (2000). Price regulation of telecommunication services: TRAI's first tariff order. Vikalpa, 25(1), 43-54. https://doi.org/10.1177/0256090920000113

Snyder, H. (2019). Literature review as a research methodology: An overview and guidelines. Journal of Business Research, 104(July), 333-339. https://doi.org/10.1016/j.jbusres.2019.07.039

Taylor, J. E., Moldoveanu, M., \& Taylor, J. L. (2013). Product Characteristics and the Effectiveness of Dow's Countermeasure for Predatory Pricing. International Journal of the Economics of Business, 20(1), 1-14. https://doi.org/10.1080/13571516.2012.750043

Torraco, R. J. (2016). Writing Integrative Literature Reviews: Using the Past and Present to Explore the Future. Human Resource Development Review, 15(4), 404-428. https://doi.org/10.1177/1534484316671606

Tumlinson, J. (2016). The Palgrave Encyclopedia of Strategic Management. The Palgrave Encyclopedia of Strategic Management, 1-2. https://doi.org/10.1057/978-1-349-94848-2

Tyner, A., \& Gershenson, S. (2020). Conceptualizing grade inflation. Economics of Education Review, 78, 102037. https://doi.org/10.1016/j.econedurev.2020.102037

Vernon, J. A., Golec, J. H., \& Keener Hughen, W. (2006). The economics of pharmaceutical price regulation and importation: Refocusing the debate. In American Journal of Law and Medicine (Vol. 32, Issues 2-3, pp. 175-192). American Society of Law, Medicine and Ethics. https://doi.org/10.1177/009885880603200203

Weisman, D. L. (2002). The Law and Economics of Price Floors in Regulated Industries. Antitrust Bulletin, 47(1), 107-131. https://doi.org/10.1177/0003603X0204700105

Yesikar, V., Mahore, R. K., Dixit, S., Shivram, G., Parmar, S., \& Jain, C. (2015). a Study To Evaluate 
Inflation and Price Rise: Effect on Common Man. Journal of Evolution of Medical and Dental Sciences, 4(30), 5172-5178. https://doi.org/10.14260/jemds/2015/755

Zhang, X. B., Fei, Y., Zheng, Y., \& Zhang, L. (2020). Price ceilings as focal points to reach price uniformity: Evidence from a Chinese gasoline market. Energy Economics, 92, 104950. https://doi.org/10.1016/j.eneco.2020.104950 